third, a system of land-parcelling surveys adapted to the economic uses of the several classes of lands; and, fourth, such recommendations as they may deem wise in relation to the best method of disposing of the public lands of the western portion of the United States to actual settlers.

"The publications of the Coast and Interior Survey shall consist of the annual report of operations, such geographic and topographic maps, and geodetic and coast charts, and such discussions and treatises connected therewith, as the superintendent shall deem of value. The publications of the Geological Survey shall consist of the annual report of operations, geological and economic maps illustrating the resources and classification of the lands, and reports upon general and economic geology and palæontology. The annual report of operations of the Coast and Interior Survey and of the Geological Survey shall accompany the annual report of the Secretary of the Interior. All special memoirs and reports of both surveys shall be issued in uniform quarto series. The style and scale of the cartographic publications shall be determined by the head of each organisation, so as to express the scientific results in the most effective manner. Three thousand copies of each shall be published for scientific exchanges by the heads of the surveys and for sale at the price of publication; and all literary and cartographic materials received by the heads of the surveys in exchange shall be the property of the United States, and form a part of the libraries of the two organisations; and the money resulting from the sale of such publications shall be paid into the Treasury of the United States."

\section{HEINRICH GEISSLER}

A YEAR since we were called upon to chronicle the death of Ruhmkorff, whose name is so closely identified with the history of electricity. In recording the death of Dr. Heinrich Geissler at Bonn, January 24, we regret the loss to the world of science of an equally important and esteemed worker. He was born in the village of Igelshieb, in Central Germany, in the year 1814. At an early age he mastered the art of glass-blowing-an industry which has long flourished in his native duchy of Sachsen-Meiningen-and for a number of years he led the life of a German Handwerksbursch, rambling from one place to another, accepting employment wherever it was offered. The German University towns offered to him the chief attraction, the preparation of the articles requisite for scientific research having for him a peculiar fascination; and his wandering life finally ended in a permanent settlement at Bonn. Here he developed rapidly. In the treatment of glass before the blowpipe he attained a degree of perfection hitherto unknown, and in his day unsurpassed. Despite the disadvantages of his early life, and the demands of his occupation, he succeeded in making rapid acquisitions in various departments of the natural sciences; and favoured by association with numerous leading celebrities, in physics and chemistry, he soon attained a remarkably comprehensive and intimate familiarity with scientific facts and principles. The union of this knowledge with his constructive ability and manualaccomplishments was productive of the happiest results, and the past thirty years have witnessed a constant succession of novel and ingenious devicesfor the furtherance of scientific discovery, issuing from his atelier. Not only was he able to accomplish the practical realisation of the designs submitted to him, but in a multitude of cases, when simply the end in view was proposed to him, Geissler planned and produced apparatus of the most delicate construction, and exact precision, involving a mastery of physical laws to be expected only in one who had devoted his life to the solution of scientific problems. The impuise thus given by him to the march of original investigation is not easy to measure, for his name is rarely associated with the numerous discoveries where his fruitful ideas have contributed in a greater or less degree to the successful result. One of his earliest direct investigations was in companionship with the distinguished physicist, Plücker, in 1852. By means of a delicate apparatus, in which the expansion of the glass was exactly compensated by the introduction of mercury, they made a series of accurate observations on the expansion of water, and established the maximum of density at $3.8^{\circ}$. With an equal degree of accuracy the coefficient of expansion for $I^{\circ}$ of ice between $-24^{\circ}$ and $-7^{\circ}$ was established at o'oor 585 , and the coefficient of expansion for water when freezing at $0^{\circ}$, was ascertained to be 0.09195 . In 1869, Geissler, in company with Vogelsang, demonstrated in an ingenious manner the presence of liquid carbonic acid in the cavities of topaz and quartz. The minerals were decomposed by means of a galvanic current, the resultant gases were collected in a vacuum, and the presence of $\mathrm{CO}_{2}$ was shown by the electric arc. They succeeded, likewise, in producing a precipitation in lime-water, and established beyond doubt the character of the liquid present. Shortly after Geissler succeeded in changing ordinary phosphorus into the amorphous state by the action of the electric current.

The apparatus with which Geissler's name is most popularly associated consists in the famous tubes arranged for the exhibition and study of the phenomena accompanying the electric discharge in various gases and vapours. Their ingenious disposition has contributed much to the progress of research on the nature of the electric light and the condition of matter in the gaseous state. Scarcely less important are his inventions of the vaporimeter, the mercury air-pump, as well as the balances, normal thermometer, and normal areometer, and other instruments of precision devised by him, which have rendered such incalculable service to those engaged in exact research. A few years since the University of Bonn rendered a fitting tribute to the varied merits of Geissler by bestowing on him the honorary title of Doctor of Philosophy.

The career of Geissler was in many respects similar to that of Rubmkorff. Both advanced from the lowest ranks of life to positions of honour in the scientific world, both gave, in a quiet and almost unrecognised manner, an important impulse to the cause of physical investigation, and both have left their names as "household words" in the nomenclature of the science to which they were so faithfully devoted.

T. H. N.

\section{GEOGRAPHICAL NOTES}

LIEUT. WEYPRECHT informs us, with reference to his proposed scientific expedition to Novaya Zemlya that the statements which have appeared are very inaccurate, nothing having as yet been decided. He and Count Wilczek certainly intend to go there and make one year's thorough scientific observation in some place on the northern coast; special attention will be given to cosmical physics. They would prefer, however, if in other places of the Arctic and Antarctic regions, others would make observations simultaneous with them. Before the war broke out they had the best hopes of seeing their proposals nearly everywhere accepted, but the disturbed state of Europe during the last two years has prevented them from taking further steps. In April the International Meteorological Congress, which was to have met in 1877 , will meet in Rome. One of the questions to be decided there will be, in what manner the Congress can contribute to the realisation of the proposals of Count Wilczek and Lieut. Weyprecht. On the decision come to at that meeting will theirs mainly depend. The programme which it is intended to carry out will be found described in NATURE, rol. xvii. p. 29. 
THE commemoration of the centenary of Cook's death by the Paris Geographical Society on Friday seems to have been thoroughly successful. Several addresses were given, showing the services done by Cook to geography, to humanity, to navigation, and to science. M. Huber gave an account of Cook's career, showing how he dispelled the tenacious notion of an Antarctic continent, gave England New Zealand and Australia, discovered a multitude of islands, simplified nautical astronomy, studied oceanic currents, the variations of the compass, and the "Aurora Australis," laid down principles of hygiene, still of value, and opened new horizons to civilisation and religion. He paid a tribute to Cook's care of his crews, his mildness and forbearance towards the natives, his resort to reprisals only when the interests of the expedition or the lives of his men were imperilled, his intrepidity and inventiveness. In connection with Cook's death, M. Huber briefly adverted to the native account of the tragedy, as published four years ago by $M$. de Varigny, fourteen years a member of the Sandwich Islands Government. It is in the shape of a poem on Captain Cook, attributed to Kupa, an eye-witness of what happened. It describes how two forests were seen gently floating on the waters; how Kupa and others were ordered to swim up to them; how they found Goords, who breathed out fire and smoke from their nostrils and mouths, had dazzling white skins and sparkling eyes, wore skins of various colours, with holes in the sides, into which they plunged their hands, and which appeared full of treasures. A god with his thunderbolt kills Kupa's father, whereupon the other swimmers take to flight. The priest declares that the floating island is the war vessel of the god Lono, who, after murdering his wife through jealousy, left Hawaii long ago to explore the seas, and had now returned, according to his promise, after six generations. He bids the natives take them bananas, cocoa-nuts, and oranges, which are accepted. At night Lono and his fellow-gods shoot hissing arrows of fire at the stars, making some of them fall into the sea. Flames of strange colours descending from the trees of the floating islands and extraordinary sounds alarmed the natives. Next morning Lono lands; is treated as a god, with sacrifices and prostrations; but whether from anger, or from having forgotten the language, he makes no answer. Several of his inferior gods seize on sacred fish destined for the altar. Others begin pulling up the palisades surrounding the sacred inclosure, the Morai, where the elders meet. King Kalaimano remonstrates, but they laugh and persist. Lono comes up, crosses the sacred boundary, and is about to enter the Morai. Kalaimano intercepts his progress, but Lono rudely pushes him away. Kalaimano takes Lono up in his arms, and, on his struggling to free himself, presses him lightly. Lono cries out with pain. "He cries, so he is not a god," exclaims Kalaimano, and kills him. The other gods, who were pulling up the stakes, fily, but the natives fall on them, and, strange to say, their blood flows like that of mortals. Kalaimano, however, while launching arrows from the shore is killed by the invisible fire. Thus your fathers, concludes. Kupa, saw the death in one day of their god and their chief. In this song the two visits of the vessels are fused into one. This confirms the story we referred to last week, and the impression that it was not treachery but vexation and disappointment that led to Cook's death. Much surprise, the Times correspondent states, was expressed in conversation at the inaction of the London Geographical Society. In Paris not only was a special festival organised with collections, which remained on view till Monday, but the Society has inserted in its Bulletin Mr. James Jackson's catalogue of the 300 works published in various languages relating to Cook. Dr. Hamy referred to Cook's observation of the transit of Venus at Tahiti, the rivalry and attacks of Dalrymple, and the fate of Cook's collections in being buried in an Austrian museum. He described Cook as ranking with Columbus and Magellan.
WE understand that the forthcoming number of the Monthly Record of Geography, published by the Royal Geographical Society, will contain a full bibliography and cartography of Zulu Land.

THE Russian Geographical Society proposes to give its great gold medal to Prof. Nordenskjöld.--The Berlin Geographical Society has given its gold medal to $M$. Prjvalsky.

WE hear that Capt. Henry Sengstacke, who had intended to accompany Dr. Otto Finsch in his projected scientific expedition among the islands of the Pacific, is shortly about to proceed to Behrings Straits for the relief of Prof. Nordenskjöld. Capt. Sengstacke took a leading part in recent German Arctic expeditions, and had but lately returned from the west coast of America. At his special request the Council of the Royal Geographical Society have, we understand, undertaken to furnish him with copies of the sailing directions for, and the latest and best charts of, the part of the world which he is now about to visit. The latest information, however, with regard to the relief of Nordenskjöld's party seems to be contained in the following telegram received by the Russian Government from the Governor-General of East Siberia :-_" Irkutsk, January 28.--Sibiriakoff telegraphs to me from Zurich that a steamer belonging to Bennett will, immediately after the opening of the navigation, proceed from San Francisco to Behrings Straits to assist Nordenskjöld. It is therefore not necessary to send a steamer from Nicolajefsk."

AT the last meeting of the Berlin Academy of Sciences an account was'given of the programme of Dr. Finsch's journey, the cost of which will be defrayed by the Humboldt Fund, and which is estimated at about 13,000 marks $(650 l$.$) . Dr. Finsch will direct his principal atten-$ tion to Polynesia. He will proceed to Honolulu viâ New York and San Francisco ; thence he will visit the Marshall and King'smill group, the Caroline, Mary Anne, and Bonin Islands, and he intends to return viâ Japan, China, and the Philippine Islands.

\section{MOVING OF HEAVY ORDNANCE}

$\mathrm{M}$

DELS of the poop and topgallant forecastle decks of H.M.S. Iris, and midship main deck of H.M.S. Dwarf, are now exhibited by Mr. George Fawcus at the floating dock, North Shields, to explain how naval ordnance can be traversed and trained round elliptical or circular sterns and parabolic bows of vessels, from side to side amidships, or from a point blank or direct broadside, to a fore and aft range of barbette or over all fire "all round" without any changing of pivots; and how muzzle-loading guns can be turned round to load in board, to aroid the inconvenience of loading in front, and thus obtain all the presumed advantages of breechloading ordnance.

A simple and compact mechanical motion has been developed from the action of the trammel or elliptograph, and is communicated rapidly along the diameters or minor and major axis of an ellipse or oval, as a shorter road than slowly round the circumference, with a small elliptical circuit instead of a circular segment of a larger circle. Two moving pivots replace a single central one. These pivots mutually assist each other to produce a reciprocal compound lever movement, one good graceful turn being succeeded by another, and are kept each in its own track of two intersecting straight lined grooves, which may be adjusted, by various angles of intersection and varied distances of the centres apart from each other, to obtain any imaginable curvilinear movement, so that guns of all kinds can be worked in less space with greater ease of movement, and therefore with less labour and waste of time, than has ever yet been previously effected. 